Egypt. Acad. J. biolog. Sci., 2(1):9 - 15 (2011)

Email: egyptianacademic@yahoo.com

Received: $26 / 6 / 2010$
H. Botany

ISSN 2090-3812

www.eajbs.eg.net

\title{
Effect of chromium toxicity on growth, chlorophyll and some mineral nutrients of brassica juncea $\mathrm{L}$.
}

\author{
Abdul Ghani \\ Department of biological sciences, University of Sargodha.
}

\section{ABSTRACT}

Effect of different concentrations of chromium on growth, chlorophyll and mineral nutrients was investigated. Increasing concentrations of chromium caused reduction in growth, chlorophyll contents and mineral mutrients of brassica. At increasing concentrations of chromium, all the attributes were found to be reduced.

Key words: Chromium Growth, Chlorophyll, Mineral nutrients, Brassica (Brassica juncea L.), toxicity.

\section{INTRODUCTION}

Chromium is a heavy metal with risk to human health. Its presence in agricultural soils can be attributed to the use of organic wastes as fertilizer and the use of waste water for irrigation (Baxter et al., 1983). Increase of world population has resulted in the pollution of the environment. The main factor responsible for pollution and other type of environmental degradation in any community are combined effects of pollution increased, effluents and technology (Medows et al., 1992).

Chromium enters the food chain through consumption of plant material. A high concentration of $\mathrm{Cr}$ has been found to be harmful to vegetation. As the chromium concentration in plants increases, it adversely affects several biological parameters.

Ultimately there is loss of vegetation, and land some times becomes barren (Dube et al., 2003). In recent years, contamination of the environment by chromium has become a major concern. Chromium is used on a large-scale in many different industries, including metallurgy, electroplating, production of paints and pigments, tanning, wood preservation, chemical production, and pulp and paper production (Zayed and Terry, 2003). These industries have be-come especially large contributors of $\mathrm{Cr}$ pollution, which can ultimately have significant adverse biological and ecological effects. Very high levels of $\mathrm{Cr}$ (VI) contamination $(14,600 \mathrm{mg} / \mathrm{kg}$ in ground water and $25,900 \mathrm{mg} / \mathrm{kg}$ in soil) were reported at the United Chrome Products site in Corvallis, Oregon (Krishnamurthy and Wilkens, 1994). Symptoms of Cr phytotoxicity include inhibition of seed germination or of early seedling development, reduction of root growth, leaf chlorosis and depressed biomass (Sharma et al., 1995). There are many studies on Cr toxicity in crop plants.Chromium significantly affects the metabolism of plants such as barley (Hordeum vulgare) (Ali et al., 2004), citrullus (Dube et al., 2003), cauliflower (Chatterjee and Chatterjee, 2000), vegetable crops (Zayed et al., 1998), wheat (Triticum aestivumcv.HD2204) (Sharma et al., 1995) and maize (Zeamays) (Sharma and Pant, 1994).

Chromium is highly toxic non-essential element for microorganism and plants (Cervantes et al., 2001). The source of chromium in environment are both natural and anthropogenic, natural source include burning of oil and coal, petroleum from Ferro chromate refractory material, chromium steels, pigments oxidants, catalyst and fertilizers This element is also used in metal plating tanneries and oil well drilling (Abbassi et al., 1998). Sewage and fertilizers are also the sources of 
chromium (Pil ay et al., 2003). Chromium has its effect on certain enzymes such as catalase, peroxidase, a cytochrome oxidase, which have iron as constituent. Agarwala et al. (1962) in barley, has reported stimulation of catalase activity at excess supply of chromium. Marked toxicity of chromium was found with respect to photosynthetic pigment, photosynthesis, nitrate reductase activity and protein content of some alga (Rai et al., 1992). The direct interaction of metal with cellular components can initiate variety of metabolic responses final y leading to a shift in the development of the plant (Assche and Clijsters, 1990). Chromium toxicity produces chlorosis and necrosis in plants (Cervantes et al., 2001). Several polluting metal and compounds are discharged into the water streams by tanneries. With these aspects in view, the present investigation was made to study the effect of different concentrations of chromium on the growth, chlorophyll and mineral nutrients of Brassica.

\section{MATERIALS AND METHODS}

Brassica seeds were sown in the earthen pots filled with loamy soil. In each pot 8 seeds were sown and after germination five plants were retained in each pot by thinning process. Sub soil water was pumped out and applied to the plants as and when required. The experimental design was completely randomized with 3 replications (Steel, et al. 1996). The treatments were randomized in order to eliminate experimental bias. All crop protection measures were adopted to ensure a good crop health. Eight $\mathrm{Cr}$ levels ranging from 5,10,15,20,25,30,35,40 ppm per kg soil including distilled water and applied to fifteen days old Brassica seedlings grown in soil with $\mathrm{pH}$ around 8 .Applications of chromium up to 5ppm had nominal effect, while there was no plant survival beyond $40 \mathrm{ppm}$ therefore $\mathrm{Cr}$ levels selected for this study were 0 (control)10,20,30 and $40 \mathrm{ppm}$. Normal growth conditions were ensured and pots were irrigated whenever needed to keep the soil moisture to field capacity. These levels were applied to Brassica seedlings and plants were grown for 15 days after treatment application before harvest.The nutrient solution had the following composition: as $\mathrm{Ca}(\mathrm{NO} 3) 3.4 \mathrm{mM} ; \mathrm{KNO}_{3} 5 \mathrm{mM} ; \mathrm{MgSO}_{4}-2 \mathrm{mM}, \mathrm{KH}_{2} \mathrm{PO}_{4}-1.02 \mathrm{mM}$; as $\mathrm{ppm}-\mathrm{H} 3 \mathrm{BO} 3 \quad 92.2 \mu \mathrm{M} \quad \mathrm{MnSO}_{4} 2.19 \mu \mathrm{M}, \mathrm{ZnCl} 21.62 \mu \mathrm{M} \mathrm{CuSo}_{4} 0.69 \mu \mathrm{M}$, $\mathrm{Na}_{2} \mathrm{MoO}_{4} ; 0.29 \mu \mathrm{M}$ Na-Fe-EDTA $0.15 \mu \mathrm{M}$ each. All the salts were dissolved and mixed after autoclaving separately. Final $\mathrm{pH}$ of the solution was adjusted as 6.7.

\section{Chlorophyll (a, b, and total) analysis}

Pigment contents of 15 days old plants were extracted by using the formula of Arnon (1949). The leaves were chopped into small pieces that were extracted with $80 \%$ acetone. The absorbance was measured at $645 \mathrm{~nm}$ and $663 \mathrm{~nm}$ for chl a,b and total chl respectively by using spectrophotometer (Hitachi Model-U 2001 Japan).

Then chlorophyll a, b \& total chlorophyll were calculated according to the Lichtenthaler and Wellburn (1983) formulae.

$\mathrm{Chl} \mathrm{a}\left(\mathrm{mg} \mathrm{g}^{-1}\right.$ leaf fresh weight $)=[12.7($ OD663 $)-2.69($ OD645) $] \times \mathrm{V} / 1000 \times \mathrm{W}$.

$\mathrm{Chl} \mathrm{b}\left(\mathrm{mg} \mathrm{g}^{-1}\right.$ leaf fresh weight $)=[22.9($ OD 645$)-4.68($ OD663 $)] \times \mathrm{V} / 1000 \times \mathrm{W}$.

Total Chl $\left(\mathrm{mg} \mathrm{g}^{-1}\right.$ leaf fresh weight $)=[20.2($ OD645)-8.02(OD663) $] \times \mathrm{V} / 1000 \times \mathrm{W}$.

Where

OD $\quad$ Optical Density.

$\mathrm{V} \quad=$ Volume of sample.

$\mathrm{W} \quad=$ Weight of sample.

Chromium Chloride was used to produce Cr (VI) concentration of 10, 20, 30 and $40 \mathrm{ppm}$. Growth in terms of root length, shoot length, root dry weight, shoot dry weight were measured at regular intervals. Chlorophyl contents and mineral nutrients were estimated respectively by the method of Petering et al. (1940), Dubais et al. 
(1956), Lowry et al. (1951) and Jackson (1962).

\section{RESULTS AND DISCUSSION}

Table1. Effect of different concentrations of chromium on growth and chlorophyll contents of brassica.

\begin{tabular}{|l|l|l|l|l|l|l|}
\hline \multirow{2}{*}{ Parameters } & \multicolumn{7}{|c|}{ Treatments } \\
& \multicolumn{7}{|c|}{ Chromium concentrations } \\
\cline { 2 - 7 } & Control & $\mathbf{1 0} \mathbf{~ p p m}$ & $\mathbf{2 0} \mathbf{~ p p m}$ & $\mathbf{3 0} \mathbf{~ p p m}$ & $\mathbf{4 0} \mathbf{~ p p m}$ & C.D at 5\% \\
\hline shoot Length(cm) & $10.50 \pm 0.285$ & $9.370 \pm 0.365$ & $8.750 \pm 0.06$ & $8.350 \pm 0.214$ & $7.390 \pm 0.211$ & 1.14 \\
\hline Root length (cm) & $9.745 \pm 0.023$ & $7.92 \pm 0.080$ & $6.950 \pm 0.021$ & $5.190 \pm 0.088$ & $4.980 \pm 0.077$ & 0.21 \\
\hline Root dry weight (g) & $1.90 \pm 0.022$ & $1.20 \pm 0.024$ & $1.11 \pm 0.021$ & $0.13 \pm 0.026$ & $0.09 \pm 0.023$ & 0.11 \\
\hline Shoot dry weight (g) & $3.80 \pm 0.023$ & $3.01 \pm 0.021$ & $2.01 \pm 0.023$ & $1.97 \pm 0.024$ & $1.01 \pm 0.026$ & 0.13 \\
\hline $\begin{array}{l}\text { Chlorophyll concentration } \\
\text { (mg/g F.W) }\end{array}$ & $1.950 \pm 0.000$ & $1.650 \pm 0.000$ & $1.660 \pm 0.000$ & $1.520 \pm 0.000$ & $1.470 \pm 0.000$ & 0.03 \\
\hline
\end{tabular}

Value represented in mean $\pm \mathrm{SD}$ with three replicates.

Table 2: Effect of different chromium concentrations on mineral contents of brassica.

\begin{tabular}{|c|c|c|c|c|c|c|c|}
\hline \multicolumn{8}{|c|}{ Elements } \\
\hline & $\mathrm{N}$ & $\mathrm{P}$ & $\mathrm{K}$ & $\mathrm{Na}$ & $\mathrm{Ca}$ & $\mathrm{Fe}$ & $\mathrm{Zn}$ \\
\hline \multicolumn{7}{|c|}{ Treatment $\mathrm{ppm} \mathrm{Cu} \quad \mathrm{mg} / 100 \mathrm{~g}$ air dry weigh } & ppm \\
\hline 0 & $1.08 \pm .3$ & $1.32 \pm 0.05$ & $3.98 \pm 0.3$ & $.46 \pm 0.06$ & $2.6 \pm 0.3$ & $426 \pm 5$ & $138 \pm 3$ \\
\hline 10 & $1.09 \pm .3$ & $1.26 \pm .06$ & $1.89 \pm .1 * *$ & $1.86 \pm .2 * * *$ & $2.32 \pm .3$ & $366 \pm 5$ & $143 \pm 3$ \\
\hline 20 & $1.18 \pm .3$ & $0.95 \pm 0.02 * *$ & $1.83 \pm 0.1 * *$ & $1.56 \pm 0.1 * * *$ & $2.09 \pm 0.3$ & $299 \pm 4 * * *$ & $145 \pm 1$ \\
\hline 30 & $1.12 \pm 3 * *$ & $0.69 \pm 0.03 * * *$ & $1.52 \pm 0.4$ & $0.81 \pm 0.02 *$ & $1.9 \pm 0.2 * *$ & $395 \pm 3 * *$ & $110 \pm 1 * *$ \\
\hline 40 & $0.82 \pm 0.2 * * *$ & $0.66 \pm 0.01 * * *$ & $0.84 \pm 0.05 * * *$ & $0.7 \pm 0.02 *$ & $1.63 \pm 0.02 * *$ & $324 \pm 3 * *$ & $99 \pm 2 * * *$ \\
\hline
\end{tabular}

Increasing concentrations of chromium caused significant reduction in root length and shoot length. Root dry weight and shoot dry weight were also significantly decreased at 10,20,30 and $40 \mathrm{ppm}$ of chromium as compared to control. Chlorophyll contents were also found to be reduced at increasing levels of same element.

Several workers have reported symptoms like reduced growth, chlorosis, necrosis, leaf epinasty, red brownish discolouration due to metal phytotoxicity (Lepp, 1981; Woolhouse, 1983). Reduced growth of tomato plants due to presence of chromium in nutrient solution was reported by Moral et al. (1995). Reduced growth in terms of root and shoot lengths at increasing doses of chromium might be due to adverse effect of this metal on auxin synthesis in brassica plants more so during early stages of their growth.

Barton et al. (2000) observed that $\mathrm{Cr}$ addition inhibited shoot growth in Lucerne cultures. Sharma and Sharma (1993) reported that after 32 and 96 days plant height reduced significantly in wheat cv.up2003 in a glass house.

\section{Tissue nutrients concentration:}

The increase in the concentration of chromium in the soil from 10-40 ppm was accompanied by the alterations of the shoot concentrations of nutrient elements. (Table 2) Increasing chromium concentrations from 10- $40 \mathrm{ppm}$ in the soil decreased the N, P, K, Ca and Fe contents of brassica juncea shoot system. This is in agreement with that of (Moral et al., 1995) who found that the increase of stress in the growth medium was followed by a marked decrease in $\mathrm{Ca}$ and $\mathrm{K}$ contents. This inhibition of uptake may be due to increased competition. At high $\mathrm{Cr}$ concentrations where severe root was observed, reduced uptake of these elements may be due to breakdown of membrane function. The concentrations of $\mathrm{N}, \mathrm{K}, \mathrm{P}$ and $\mathrm{Ca}$ in treatment were below the concentrations considered enough for plant growth [ ]. This was despite the concentration these elements in soil solution being within the range considered enough for the growth of plants in solution culture. The effect of $\mathrm{Cr}$ toxicity resembles 
$\mathrm{Al}$ toxicity, in that $\mathrm{Al}$ is a strong inhibitor of $\mathrm{Ca}$ and $\mathrm{Mg}$ uptake (Chatterjee and Chatterjee 2000). A slight depletion in $\mathrm{K}$ concentration was observed. This may be attributed to $\mathrm{K}$ efflux as part of a mechanism of $\mathrm{Cr}$ tolerance.[ ]

Further, excess amount of chromium might have negatively affected the translocation of iron in the leaf of brassica plants. Earlier also several workers have reported inhibition of chlorophyll biosynthesis by metal in higher plants (Baszinsky et al., 1980, Prasad and Prasad, 1987) and in algae (Defil ippis and Pal aghy, 1976 and Hamp and Ziegler, 1981). Some heavy metals including chromium in excess amount may result into chlorosis, caused by change in concentration of essential mineral nutrients. It may also cause reduced photosynthesis resulting from stomatal closure and also reduced intercellular spaces and alteration within chloroplast (Vazquez et al., 1987). Excess amount of cobalt, chromium and copper had an adverse effect on biomass, concentration of iron, chlorophyl "a" and " $b$ ", protein and catalase activity in cauliflower (Chatterjee and Chatterjee, 2000).

\section{REFERENCES}

Abbassi, S.S.; Abbassi, N. and Soni, R. (1998). Heavy metals in the environment, Mittal Publication, New Delhi, India.

Abbassi, S. S. and Soni, R. (1985). Environmental management and treatment of chromium. J. Inst. Eng., 65:113-117.

Agarwala, S. C. and Kumar, A. (1962). The effect of heavy metals and bicarbonate excess on sun flower plants grown in sand culture with special reference to catalase peroxidase. J. Ind. Bot. Soc., 41:72-77.

ALI NA, Ater M.; Sunahara, Gl. and Robidoux, P.Y. (2004). Phytotoxicity and bioacuumulation of copper and chromium using barley (Hordeum Vulgare L.) in spiked artificial and natural forest soils. Ecotoxicology and environmental safety 57: 363-374.

Assche F. Van and H. Clijsters: Effects of metals on enzyme activity in plants. Plant Cell Environ., 13:195-206 (1990).

Baszinsky, T. L.; Wajda, M.; Krol, D.; Wolinska, Z. Krupa and Tukendraf, A. (1980). Photosynthetic activity of cadmium treated tomato plants. Physiologia Plantarum, 48:365-370.

Bisht, S. S.; Sharma, C. P. and Kumar, A. (1976). Plant response to excess concentration of heavy metals. Geophytol., 6 (2):296-307.

Cervantes, C.; Campos-Garcia, J.; Debars, S.; Gutierrez-Corona, F.; Loza-Tavera, H.; Carlos-Tarres-Guzman, M. and Moreno-Sanchez, R. (2001). Interaction of chromium with Microgenesis and plants. FEMS Microbiol. Rev., 25: 335-347.

Chatterjee, J. and Chatterjee, C. (2000). Phytoxicity of cobalt, chromium and copper in Cauliflower. Environ. Pollut., 109:69-74.

Defillippis, L. F. and Pal aghy, C. K. (1976). The effect sub-lethel concentration of mercury and zinc on chlorella, II photosynthesis and pigment composition Zeits Chrift Fiir. Pflanzenphysiologie., 78:314-322.

Dubais, M. K. A.; Hamilton, J. K.; Rebos, P. A. and Smith, F. (1956). Calori metric method for determination of sugar and related substances. Anal. Chem., 28:350-356.

Euler, H. V. and Josephson, K. (1927). Uber katalase. Leibigs Ann., 452:158-184.

Dube, B.K.; Tewari, K.; Chatterjee, J. and Chaterejee, C. (2003). Excess chromium alters uptake and translocation of certain nutrients in citrullus. Chemosphere 53: $1147-1153$. 
Hamp, R. and Ziegler, H. (1981). The effects of sublethel concentration of zinc, cadmium and mercury on euglena. Growth and pigments Zeichrift fiir. Pflanzenphysiologie., 101:37-47.

Krishnamurthy, S. and Wilkens, M.M. (1994). Environmental chemistry of Cr. Northeasteren geology 16: 14-17.

Lepp, N.W. (Ed:) (1981). Effect of heavy metal pollution on plants vol 2 Applied Science Publishers London.

Lowry, O.H.; Rosenbrough, N. J.; Farr, A. L. and Randall, R. J. (1951). Protein measurement with the folin phenol reagent. J. Biol. Chem., 193:265-275.

Luck, H. (1963). Peroxidase. In: Method in enzymatic analysis. (Ed: H.U. Bergmeyer). Academic Press, New York and London. pp.895-897.

Moral, R.; Pedreno, N.; Gomez, I. and Matrix, J. (1995). Effect of chromium on nutrient element content and morphology of tomato. J. Plant Nutrition, 18 (4):175-183.

Meadows, D.H.; Meadows, D. L. and Randers, (1992). Beyond the limits Earthscan publication, London.

Petering, H. H.; Wolman, K. and Hibbard, R. P. (1940). Determination of chlorophyll and carotin in plant tissue. Ind. Eng. Chem., Ann., Ed.,12:148-151.

Pillay, A. E.; Williams, J. R.; EL Mardi, M. O.; AI-Lawati, S.M.H.; AI-Hadabbi, M. H. and AI-Hamdi, A.(2003). Risk assessment of chromium and arsenic in date palm leaves used as livestock feed. Environ. Intl., 1048:1-5.

Prasad, D. D. K.; Prassad, A. and Prassad, R. K. (1987). Altered $\delta$ - aminolaevulinic acid metabolisms by lead and mercury in germinating seedlings of bajira (Pennisetum typhoideum). J. Plant Physol., 127:241-249.

Rai, U. N.; Tripathi, R. D. and Kumar, N. (1992). Bioaccumulation of chromium and toxicity on growth, photosynthetic pigments, photosynthesis, in vivo nitrate reductase activity and protein content in chlorococcalear green alga, Glaucocystis nostochinearum ltzigsohn. Chromosphere, 25:721-732.

Sharma, D.C. and Pant R. C. (1994). Chromium uptake its effects on certain plant nutrients in maize (Zea mays L. CV Ganga 5). Journal of environmental science and health, Part A 29: 941-948

Sharma, D. C.; Chatterjee, C. and Sharma, C. P. (1995). Chromium accumulation by barley seedlings (Hordeum vulgare L,). Journal of experimental botany 25: 241-251.

Tandon, P. K.; Srivastava, M. and Gupta, S. (2000). Response of moong (Phaseolus radiatus L.) seeds to excess concentration of certain heavy metals. Biol. Memoirs, 26 (2):56-61.

Vazquez, M. D.; Poschenrieder, C. and Barcelo, J. (1987). Chromium VI induced structural and ultrastructural changes in Bush bean plants. Annals of Bot., 59: 427-438.

Woolhouse, H. W. (1983). Toxicity and tolerance in the responses of plant metals. In: Encyclopedia of plant physiology. Vol.12 C. (Eds: Lange et al.). pp. 245-300. Springer Verlog. Berlin.

Zayed, A.; Lytle C.M.; Qian, J.H. and Terry, N. (1998). Chromium accumulation, translocation and chemical speciation in vegetable crops, planta 206: 293-299.

Zayed A. M. and Terry N. (2003). Chromium in the environment: factors affecting biological remediation. Plant and soil 249: 139-156. 